\title{
Krill Yağı ve Sağlık Faydaları
}

\author{
Burçin ÖZÜPEK 國 ${ }^{1}$, Didem DELIORMAN ORHAN 國 1
}

\section{ÖZ}

Krill yă̆ı, okyanuslarda yaşayan "Euphausia superba" isimli deniz canlısından elde edilen bir maddedir. Krill yağında yüksek oranda Omega 3 yağ asitleri bulunur ve bu yağ asitleri fosfolipitler şeklindedir. Ayrıca, astaksantin, A vitamini ve E vitamini içeren bir besin takviyesidir. Astaksantin kuvvetli antioksidan özelliğe sahip bir maddedir. Omega 3 yağ asit takviyelerinin; zihinsel gelişimde, hiperlipidemide, premenstrual sendromlarda, enflamatuvar ve kardiyolojik hastalıklarda önemli olduğu bilinmektedir. Son yıllarda Krill yağı balık yağından daha fazla önem kazanmıştır. Ayrıca, okyanuslarda yüzeyde yaşadıkları için toksin ve çevresel kirlilik içerme riski de daha azdır. Çalışmalarda genellikle terapötik etki için günlük doz 1-3 g olarak belirlenmiştir. Takviye edici olarak kullanıldığında ise $500 \mathrm{mg}$ dozda alınması önerilmektedir. Hamilelerde de kullanımı güvenlidir. Dokosaheksanoik asit ve Eikosapentaenoik asit içeriğinin yüksek olması Krill yağının önem kazanmasına sebep olmuştur. Ayrıca bu yağın emiliminin fazla olmasından dolayı araştırmacıların yeni odak noktası Krill yağı olmuştur. Bu makalede, Krill yağının içeriği, biyoyararlanımı, in vivo ve klinik aktivite çalışmaları, yan etkileri ile ilgili yayınlanmış olan bilimsel çalışmalar derlenmiştir.

Anahtar Kelimeler: Omega 3 yağ asitleri; karidesgiller.

\section{Krill Oil and Its Health Benefits}

\begin{abstract}
Krill oil is obtained from Euphausia superba, which lives in the oceans. Omega 3 fatty acids in Krill oil are found in the form of phospholipids. Astaxanthin is a strong antioxidant compound. Also, it is a food supplement containing astaxanthin, Vitamin A, and Vitamin E. Omega 3 fatty acid supplements; It is known to be important in mental development, hyperlipidemia, premenstrual syndromes, inflammatory and cardiological diseases. In recent years, Krill oil has gained more importance than fish oil. Also, because Krill lives on the surface in the oceans, there is less risk of containing toxins and environmental pollution. In studies, it is generally recommended to take 1-3 $\mathrm{g}$ daily for therapeutic effect and $500 \mathrm{mg}$ as a supplement. It is safe to use in pregnant women. Due to the high content of docosahexaenoic acid and eicosapentaenoic acid and the high absorption rate, the new focus of researchers has been on Krill oil. In this article, published scientific studies on the content, bioavailability, in vivo and clinical activity studies and side effects of krill oil have been reviewed.
\end{abstract}

Keywords: Omega 3 fatty acids; euphausiacea.

\section{GíRiş}

Euphausiacea familyasından olan karides benzeri kabuklulara genel olarak 'Krill' denir ve 86 türden oluşur. "Antarktika Krill”i olarak da bilinen Euphausia superba, Antarktika'yı çevreleyen bozulmamış okyanuslardaki en yaygın Krill türüdür. Birçok deniz canlısını besledikleri için besin zincirinin en alt kısmında bulunurlar (1). 1970'den beri Japonya, Rusya, Ukrayna ve Fransa'da Antartika Krill'i yiyecek olarak tüketilmektedir. 1980'li y1llarda 30.000 ton Krill toplanmış ve Japonya'da yaklaşık her yıl 6.000 tonu gıda olarak tüketilmiştir. Avrupa Komisyonu E. superba'dan elde edilen lipit fraksiyonunu güvenli bir gıda olarak tanımıştır. Gıda ve İlaç İdaresi (FDA), Krill yağını gıda olarak tüketimini Generally Recognized As Safe (GRAS) kategorisine almıştır (2). Vücutlarında ve yumurtalarında omega-3 (Eikosapentaenoik asit (EPA), Dokosaheksanoik asit (DHA)) sentezleyebilmek için alg ile beslenirler.

1 Gazi Üniversitesi, Eczacılık Fakültesi, Farmakognozi AD, Ankara, Türkiye 
Krill taze ağırlıkta \%10-11 protein, \%2-6 yăg, \%0,3-0,6 karbonhidrat, \%2 kitin ve \%3-4 kadar mineral içermektedir. Lipit içeriği cinsiyete göre büyük farklılıklar göstermektedir (3). Krill yağında ana madde olarak \%40 oranında fosfolipit (esas olarak fosfotidilkolin), \%30 EPA ve DHA omega-3 yağ asitleri, vitamin A, vitamin E ve astaksantin bulunur (1). Ayrıca flavonoid olarak da 6,8 di-C-glukozil luteolin vardır (4). Krill yağından elde edilen fosfolipitlerin ve omega-3 yağ asitlerinin, balık yağından elde edilen trigliserit ve etil esterlere oranla organizmada daha fazla emilebildiği gözlemlenmiştir (1). Bu makalede, Krill yağının omega-3 yağ asiti kaynağı olarak öneminden ve etkilerinden bahsedilecektir.

Balık yağı, Krill Yağı Farklılıkları ve Biyoyararlanım Balık yağında omega 3 yağ asitleri ve trigliseritler bulunur. Krill yağında ise omega 3 yağ asitleri, fosfolipitler, fosfotidilkolin, kolin ve astaksantin bulunur. Antarktika Krill'inin bu kombine yapısı onu balık yağından ayırmaktadır. 66 kişiyle denenmiş randomize çift kör ve paralel bir çalışmada, 3 deney grubu oluşturulmuştur. Günlük doz 1,3 g olarak belirlenmiştir. İlk grup balık yağındaki omega 3 yağ asitlerini, ikinci grup balık yağındaki trigliseritleri ve son grup da Krill yağını 4 hafta boyunca kullanmışlardır. Kandaki konsantrasyonları değerlendirildiğinde Krill yağının plazma konsantrasyonları daha yüksek bulunmuştur (5). $\mathrm{Bu}$ sonuçlara göre, daha az miktar Krill yağı alınarak daha yüksek dozdaki balık yağının etkisinin gözlenebileceği önerilmiştir (1). Krill yapısındaki omega 3 yă asitlerinin fosfolipitlere bağlanmasından dolayı suda çözünebilmesi, balık yağındaki omega-3 yağ asitlerinin çözünememesiyle ilişkilendirilmiştir (3). 122 kişi ile yapılan başka bir çalışmada 3 deney grubu belirlenmiştir. 1. gruba 6 kapsül Krill yağı $(n=36 ; 3,0$ g/gün, EPA+DHA=543 mg), 2. gruba 3 kapsül balık yağ ( $\mathrm{n}=40$ 1,8 g/gün, EPA+DHA=864 mg) ve kontrol grubu olan 3. gruba herhangi bir yağ verilmemiştir. Deney süresi 7 hafta olarak belirlenmiş ve kan plazma konsantrasyonlarındaki ölçümlere bakılmıştır. Krill yağındaki plazma konsantrasyonları daha yüksek bulunmuştur (6).

\section{Etki ve Doz}

Çok sayıda çalışma, omega-3 yağ asitlerinin tüketiminin artmasiyla gözlemlenen antitrombotik, antiaritmik, antiaterosikloretik ve antienflamatuar etkilere ait mekanizmaları tanımlamıştır. Fosfatidilkolin ve astaksantinin ilave bir etki sağlayıp sağlamadığını belirlemek için daha fazla çalışmaya ihtiyaç vardır. Fosfatidilkolin, tek başına homosistein durumunu, karaciğer bozukluklarını ve solunum sıkıntılarını düzeltmek için bir diyet takviyesi olarak umut verici görülmektedir. Astaksantinin, antioksidan özelliklerinden dolayı bağımsız pozitif etkileri olabilir. Çeşitli antioksidanların oksijen radikalini absorbe etme kapasitesi değerleri karşılaştırıldığında, astaksantinin; Koenzim Q10'dan (CoQ10) 34 kat, balık yağından 48 kat daha etkili olduğu bulunmuştur. Omega 3 yağ asitleri beyin, sinir sistemi ve göz gelişimini hızlandıran, yetişkinlerde romatoit artrit gelişimini yavaşlatan, yüksek kan trigliserit değerlerini düşüren, enfarktüs sonrası sağ kalım oranını arttıran, Alzheimer hastalığını yavaşlatan uzun zincirli yağ asitleridir. Omega-3 fosfolipitleri hücre fonksiyonlarının gerçekleşmesi ve yapılandırılması için omega-3 trigliseritlerinden çok daha etkilidir (3).

Terapötik doz günlük 1-3 g olarak, takviye edici olarak da $500 \mathrm{mg}$ dozda alınması önerilmektedir. $\mathrm{Bu}$ tip yağlardan EPA ve DHA alımı, 160 (Avustralya, Yeni Zelanda)-1000 (Japonya, Güney Kore) mg/gün olarak önerilmektedir (4).

\section{Antienflamatuvar Etki}

C57BL/6 İnsan tümör nekroz faktör alfa (hTNF- $\alpha$ ) farelerde 6 hafta boyunca yapılan bir çalışmada, bir grup yüksek yağ içerikli diyetle (\%24,5 total yağ), diğer grup balık yağı içeren diyetle ve sonuncu grup hayvanlar Krill yağı içeren diyetle (EPA: \%5,23- 5,39 DHA: \%2,82-2,36) beslenmiştir. Krill yağındaki omega-3’ler fosfolipit formunda olup triaçilgliserol ve kolesterolün plazma seviyelerini düşürerek lipit metabolizmasında etki göstermiştir. Aynı dozda kullanılan balık yağı ise Krill yağı kadar lipit katabolizması üzerinde etkili bulunmamıştır. Çalışma sonucunda Krill yağının lipit metabolizmasını daha çok düzenlediği ve monosit kemotaktik protein-1 seviyelerini önemli ölçüde düşürdüğü gözlenmiştir. Ancak, sitokin seviyelerinde anlamlı bir değişiklik oluşturmadığı tespit edilmiştir (7).

3,5 hafta boyunca Krill ve balık yağı uygulanan kollajen nedenli artrit duyarlı DBA/1 farelerde romatoit artrit parametreleri incelenmiştir. Çalışmada, bir grup kontrol grubu, bir grup Krill yağ 1 grubu (EPA + DHA: 0,44 g/100 g) ve en sonuncu grup balık yağ $10,47 \mathrm{~g} / 100 \mathrm{~g})$ olarak belirlenmiştir. Artrit şiddeti klinik skorlama sistemi ile değerlendirilmiştir. Krill yağının bu deney modelinde artrit skorları ve eklem patolojisi açısından koruma sağladığı görülmüştür. Çalışmada serum örneklerinde İnterlökin (IL-l $\alpha$, IL-1 $\beta$, IL-7, IL-10, IL-12p70, IL-13, IL-15, IL-17) ve Dönüştürücü Büyüme Faktörleri (TGF) seviyeleri de incelenmiş, Krill yağının serum sitokin seviyelerini değiştirmediği, balık yağı tüketiminin ise IL1 ve IL-13 seviyelerini yükselttiği rapor edilmiştir Çalışma, Krill yağının, enflamatuar artritin klinik ve histopatolojik belirtilerine karşı yararlı bir müdahale stratejisi olabileceğini göstermiştir (8).

Neptune Krill yağı (NK) ve Balık yağı (BY)'nın antienflamatuar ve analjezik etkilerinin in vivo olarak kemirgenlerde değerlendirildiği bir çalışmada; her iki yağda $500 \mathrm{mg} / \mathrm{kg}$ dozda test edilmiştir. NK'da ağırlıç̧a EPA \%12, DHA ise \%7 oranında iken BY'nda EPA \%12, DHA \%8 oranında bulunmaktadır. Asetik asit-nedenli kıvranma testi, sicak tabaka testi ve formalin nedenli test analjezik aktivite için, karragen-nedenli ödem testi ise antienflamatuar aktivitenin değerlendirilmesinde kullanılmıştır. Tüm çalışmalarda sonuçları kıyaslayabilmek için referans ilaçlar kullanılmıştır. Sonuçlar; NK'nın ağrı ve enflamasyon üzerinde BY'den daha etkili olduğunu göstermiştir (9).

Romatoit artrit ve kardiyovasküler hastalığı olan, C Reaktif Protein (CRP) seviyeleri de 1,00 mg/dL civarı olan 90 kişi üzerinde randomize ve çift kör yapılan klinik bir çalışmada; birinci gruba Krill yağı (\%17 EPA, \%10 DHA ve omega-3: omega-6 oranı 15:1), ikinci gruba ise plasebo (mikrokristalin selüloz) verilmiştir. Krill yağı günlük $300 \mathrm{mg}$ olacak şekilde dozlanmıştır. 7., 14. ve 30 . günlerde ölçümler alınmıştır. Krill yağı grubunda 7 ve 14 gün gibi kısa periyotlarla yapılan tedavi sonunda CRP 
düzeyleri anlamlı bir şekilde azalmış ve artrit nedenli semptomlarda da hafifleme tespit edilmiştir (10).

\section{Antihiperlipidemik}

12 hafta süren 120 kişiyle yapılmış çok merkezli, prospektif, randomize bir çalışmada, hastalar 4 gruba ayrılmış ilk gruba Krill yağı günlük 2-3 g., ikinci gruba Krill yağ1 günlük 1-1,5 g, üçüncü gruba balık yağı (gram başına $180 \mathrm{mg}$ EPA ve $120 \mathrm{mg}$ DHA içeren balık yağ (3:2, 3 g günde bir kez) ve dördüncü gruba plasebo verilmiştir. $\mathrm{Bu}$ çalışmanın sonuçları, Krill yağının total kolesterol ve Düşük Dansiteli Lipoprotein (LDL) seviyelerini azaltmada, Yüksek Dansiteli Lipoprotein (HDL) seviyelerini de yükseltmede etkili olabileceğini göstermiştir. Düşük ve eşit dozlarda Krill yağı glukoz, trigliserit ve LDL seviyelerinin azaltılmasında, balık yağından çok daha etkili olmuştur (11).

Randomize, çift kör, çok merkezli, plasebo kontrollü bir başka çalışmada Krill yağı farklı dozlarda 267 kişiye (günde 0,$5 ; 1 ; 2 ; 4$ g) verilmiştir. Başlangıç, 6. ve 12 . haftalarda LDL ve trigliserit seviyeleri ölçülmüştür. Çalışmada, Krill yağının doz bağımlı olarak serum trigliserit seviyelerini azalttığı, omega 3 indeksini arttırdığ1, LDL seviyelerini de arttırmadığ gözlenmiştir. Sonuçlar, Krill yağının kullanımının kardiyovasküler hastalık risk faktörlerini azaltabileceğini düşündürmüştür (12).

Bir başka çalışmada, sıçanlarda Krill yağının hiperlipidemi üzerindeki etkisine bakılmıştır. Bu çalışmada 4 hafta boyunca 33,3; 99,3 ve 199,8 g/L dozda hayvanlara Krill yağı verilmiş ve serum total kolesterol, trigliserit, HDL ve LDL seviyeleri ölçülmüştür. Süre sonunda Krill yağı, test edilen tüm dozlarda kolesterol, trigliserit ve LDL seviyelerini düşürürken HDL seviyelerini de anlamlı olarak yükseltmiştir. Değerler referans olarak kullanılan Lovastatin'e (100 mg/kg/gün) göre değerlendirilmiştir. Bulgular fonksiyonel bir gıda olarak Krill yağının, bazı hastalıklarda serum lipid seviyelerini kontrol edebilmek amaciyla tüketilebileceğini göstermiştir (13).

Bir başka çalışmada, 12 hafta boyunca yüksek yağlı bir diyet ve \%2,5 Krill yağı takviyesiyle beslenen sıçanların karaciğerinde trigliserit ve kolesterol birikiminin etkili bir şekilde önlendiği görülmüştür. Bu etkinin, trigliseritlerin ve glikozun plazma seviyelerinin aynı şekilde azalarak, plazma insülin artışının önlenmesiyle birlikte gerçekleştiği düşünülmüştür. Ayrıca Krill yağı takviyesinin, yüksek yağlı diyetle beslenen hayvanlarda sıklıkla görülen vücut yağının artmasını, lipit ve proteinlerin oksidatif hasarını önlediği de tespit edilmiştir (14).

2016 yılında, 25 orta derecede hipertrigliseridemik hastada (Trigliserit seviyeleri: 150-500 mg/dL) yapılan çift-kör, randomize klinik çalışmada, hastaların 4 haftalık bir süre için öncelikle diyetlerinde düzenlemeler yapmış ve önerilen egzersizlere başlamalara sağlanmıştır. Bu süre sonunda hastaların bir kısmı günde iki kez 1000 mg omega 3 etil ester çoklu doymamış yağ asitleri (\%85 EPA ve DHA, EPA/DHA oranı 0,9/1,5) içeren tablet kullanırken diğer grup hasta $500 \mathrm{mg}$ Krill yağı (EPA 75 mg ve DHA $45 \mathrm{mg}$ ) içeren tabletlerden günde iki kez almışlardır. 4 haftalık tedaviden sonra katılımcılar tedaviye ara vermişledir. Tüm katılımcıların plazma trigliserit seviyelerinde azalma tespit edilmekle beraber, omega 3 etil ester çoklu doymamış yağ asitlerinin Krill yağından daha etkili olduğu görülmüştür $(p<0,05)$. Bununla birlikte, sadece Krill yağı tedavisi omega 3 etil ester çoklu doymamış yağ asitleri tedavisi ile karşılaştırıldığında, yüksek yoğunluklu lipoprotein kolesterol ve apolipoprotein AI seviyelerini daha etkili bir şekilde iyileştirmiştir. Her iki tedavi de, yüksek hassasiyetli C-reaktif protein seviyelerini önemli ölçüde azalmıştır $(p<0,05)$, ancak Krill yağının bu parametre üzerinde omega 3 etil ester çoklu doymamış yağ asitlerinden daha etkili olduğu söylenebilir (15).

18-70 yaş arasında açlık serum trigliserit seviyesi 1,3 ve 4,0 $\mathrm{mmol} / \mathrm{L}$ arasında değişen 36 sağlıklı kişide yapılan 8 haftalık randomize paralel bir klinik çalışmada, katılımcılara balık, Krill ve kontrol yağları kullandırtılmıştır. Balık yağı grubunda, denekler diyet yönergelerine göre yağsız ve yağlı balık tüketmiştir. Krill ve kontrol grubu, günlük 4 kapsül (her kapsül 4 g yăg ihtiva etmektedir) tüketmişlerdir. Balık yağı grubunda verilen balıklardan ve Krill grubunda Krill yağından haftalık omega-3 yağ asit tüketim miktarı 4.103 ve 4.654 mg olarak hesaplanmıştır. Açlık trigliserit seviyeleri hiçbir grupta değişmezken Krill yağı kullanan grupta total lipit, fosfolipit, kolesterol, kolesteril ester ve nonesterifiye kolesterol seviyelerinde anlamlı artışlar rapor edilmiştir. Balık yağı grubunda D vitamin seviyeleri artarken; Krill yağı grubunda kan glukoz seviyeleri anlamlı bir şekilde azalmıştır. Plazma omega-3 yağ asit seviyeleri her iki grupta da artmıştır. Sonuçlar, her iki yağla da yapılan takviyenin sağlık üzerinde faydalı etkiler oluşturduğunu göstermiştir (16).

\section{Premenstrual sendrom ve Dismenore}

The Diagnostic and Statistical Manual of Mental Disorders (DSM-III-R) kriterlerine göre premenstrual sendromu olan 70 kadında yapılmış çift kör ve randomize olarak tasarlanmış bir klinik çalışmada, Krill ve balık yağı (\%18 EPA ve \%12 DHA) takviyelerinin etkileri değerlendirilmiştir. Çalışmanın ilk bir ayında deneklere, yemek aralarında yağlar günde bir kere 1 gramlık 2 adet yumuşak kapsül şeklinde kullandırılmıştır. Takip eden 2 ay süresince tedavi, menstruasyondan 8 gün önce başlayarak menstruasyonun ikinci gününe kadar (10 gün) günde 2 adet 1 gram yumuşak kapsül alınacak şekilde devam edilmiştir. 45. ve 90. günlerde ölçümler yapılmıştır. Krill yağının, dismenore ve premenstrüel sendromlarının duygusal semptomlarını önemli ölçüde azalttığı ve balık yağına kıyasla adet öncesi semptomların tedavisinde anlamlı seviyede etkili olduğu görülmüştür (17).

\section{Kognitif Fonksiyonlar ve Antidepresan Etki}

Çalışmalar, omega-3 yă̆ asitlerinin beyin sağlığında, öğrenme ve hafıza gibi beyin fonksiyonları üzerinde olumlu etkilerinin olduğunu göstermiştir. Bu bulgulardan hareketle Krill yağı sıçanlarda bu etki yönünden test edilmiştir. 7 hafta boyunca Krill yağı gida rasyonunun $\% 1,25$ 'ine tekabül eden bir dozda oral olarak verilmiştir. Verilen ortalama Krill yağ 1 dozu 0,2 g/sıçan/gün olarak hesaplanmıştır. Referans grubuna trisiklik bir antidepresan olan imipramin verilmiştir. Krill yağ imipramin gibi antidepresan benzeri etkiler gösterirken, bilişsel fonksiyonlarda artış oluşturmuştur. İmipramin ve Krill yağının etkilerinin, Bdnf mRNA ekspresyonunu arttırması ile ilişkili olduğu düşünülmüştür. Ancak Arc ve 
diğer sinaptik-plastisite ile ilişkili genlerin ekspresyonu üzerinde ikisinin farklı etkileri olduğu da öne sürülmüştür. Bu sonuçlar klinik çalışma sonuçları ile de desteklendiğinde Krill yağının, içeriğinde bulunan $n-3$ fosfolipitler ve astaksantin gibi bileşenlerinin sinerjisiyle, depresyon ve bilişsel fonksiyonlarda etkili olabileceği ve bu nedenle nörolojik ve psikiyatrik bozuklukları hafifletmek için yeni bir yaklaşım olarak önerilebileceği rapor edilmiştir (18).

EPA ve DHA'nın etil ester formunun diyete ilavesinin, hipokampus ve serebral kortekste DHA seviyelerinin artmasıyla mekânsal algıyı geliştirdiği rapor edilmiştir. Siçanlarda yapılan bir çalışmada, 3 hafta süresince Krill türevli fosfolipitlerin tüketilmesinin (yüksek doz: $300 \mathrm{mg}$ EPA ve $120 \mathrm{mg}$ DHA, düşük doz: $215 \mathrm{mg}$ EPA ve $86 \mathrm{mg}$ DHA) uzaysal öğrenme kabiliyeti, plazma ve beyin dokularının yağ asidi kompozisyonu üzerindeki etkileri araştırılmıştır. Radyal labirent testinde, referans ve çalışma belleği hatalarının Krill yağı uygulamasından sonra önemli ölçüde azaldığı görülmüştür. Yüksek doz Krill yağı uygulamasından sonra plazma ve beyin seviyeleri anlamlı şekilde artmış ve araşidonik asit seviyeleri önemli ölçüde azalmıştır. Plazma ve beyin dokularında lipid peroksidasyonu inhibe edilmiş ve dentat girus içindeki hücre oluşumu da artmıştır. Bütün bu etkilerin, EPA ve DHA'nın etil ester formlarının neden olduğu etkilere benzer olduğu bildirilmiştir (19).

\section{Vasküler Dilatasyon ve Miyokard Enfarktüsü}

Batıda kalp yetmezliği, kardiyovasküler mortalitenin en önemli nedenlerinden biridir. n-3 çoklu doymamış yăg asitleri (PUFA) takviyelerinin kalp yetmezliğinde kardiyak fonksiyonu iyileştirdiği ve miyokard enfarktüsünden (MI) sonra mortaliteyi azalttığ1 gösterilmiştir. n-3 PUFA'nın molekül yapısının ve bileşiminin farklı deniz kaynakları arasında değişiklik gösterebileceği ve bu biyolojik etkiler için de önemli olabileceği düşünülmektedir. Krill yağı yoğun bir şekilde, balık yağının aksine, n-3 PUFA'nın fosfolipit şekillerini içermektedir. Sıçanlarda yapılan bir çalışmada Krill yağının, deneysel MI sonrası kardiyak modelleme yapılarak etkileri incelenmiştir. Sıçanlar, deneysel MI oluşturulmadan Krill yağı (100 g yemdeki EPA + DHA miktarı, 0,47 g) ile 14 gün beslenmiştir. MI sonrası yedi gün, sıçanlar ekokardiyografi ile incelenmiştir. Krill yağ 1 takviyesinin, deneysel MI oluşturulmadan önce miyokard dokusundaki n-3 PUFA'nın orantılı bir şekilde artmasına neden olarak MI'ın neden olduğu sol ventrikül dilatasyonunu kontrole kıyasla anlamlı derecede azalttığ görülmüştür (20).

\section{Hamilelikte kullanımı}

126 anne ile yapılan kohort bir çalışmada annelere omega 3 yağ asitleri verilmiştir. Hamileliğin 24. haftasında deney başlamıştır ve ölçümler 28. hafta, doğumdan 3 ay sonra, doğumdan 6 hafta sonra, doğumdan 12 ay sonra olarak belirlenmiştir. Bilişsel gelişimde omega 3 yağ asitlerinin etkisi olduğu kanıtlandığı için bu çalışmada sadece problem çözme yetisine bakılmıştır. Deney sonuçları için hem kandaki omega 3 yağ asitleri miktarına hem de 4-60 ay arası anketlerle problem çözme özelliklerine bakılmıştır. Omega 3 yağ asiti alan çocuklarda problem çözme yetisi daha çok ilerlemiştir. Krill yağındaki omega 3 yağ asitlerinin daha çok emilmesi, hamilelik sırasında bu yağın kullanımının daha iyi olacağını düşündürmüştür. Sonuçlar, Avrupa Gıda Güvenliği Otoritesinin (EFSA) hamile kadınlar için günlük $200 \mathrm{mg}$ DHA alımını tavsiye ettiğini desteklemektedir. Ayrıca, FDA tarafından önerilen en son tavsiyelerle de uyumludur (21).

\section{Yan etkiler}

Krill yağı tüketimi ile ilişkili yan etkiler; gaz, şişkinlik ve/veya ishal gibi mide-bağırsak şikâyetleri olabilir (4). Trombosit fonksiyonlarında azalma ve yağlı bir cilt oluşturabilir.

\section{SONUÇLAR}

- Krill yağı bileşiminde bulunan antioksidan aktiveteye sahip astaksantinden dolayı balık yağından daha stabildir.

- Balık kokusu ve tadi yoktur.

- Balık yağında EPA ve DHA çoğunlukla 1: 1,8 oranında ve trigliserit formundadır.

- Krill yağında EPA ve DHA 2:1 oranındadır. Omega-3 içeriğinin \%30-65'i fosfolipit formundadır. Bağırsak duvarından ve kan dolaşımına geçişinin daha kolay olduğunun tespit edildiği çalışmalar mevcuttur.

- Balık veya kabuklu deniz hayvanlarına alerjisi olan insanlar, balık yağı veya Krill yağı takviyesinden kaçınmalıdır.

- Antarktika Krill’i okyanuslarda yüzeyde yaşadıkları için toksin ve çevresel kirlilik içerme riski daha azdır.

- Balık yağına göre çok daha pahalı bir yağdır.

Genel olarak, omega-3 takviyeleri (hem balık hem de kril yağ1 içerir) kan şekeri seviyelerini etkileyebilir, kan basıncını düşürebilir ve kanama riskini artırabilir, özellikle daha yüksek dozlarda veya kanama bozukluğu olanlarda veya zaten riski artıran ilaçlar alanlarda kanama yapabilir (varfarin veya aspirin gibi). Yüksek dozlarda balık yağı da A veya $\mathrm{D}$ vitamini toksisitesine neden olabilir.

Özellikle enflamasyon ve hiperlipidemi tedavisindeki elde edilen sonuçlar çok anlamlı farklılıklar göstermiştir. Sadece romatoid artrit değil diğer enflamasyon hastalıklarında da kullanılabileceği düşünülmektedir. Bu etkiler için daha ayrıntılı klinik çalışmaların yapılması gereklidir. Sonuç olarak bu tip omega 3 destekleri için mutlaka doktor veya eczacıya başvurmak, doğru ürünleri, doğru sürelerde kullanmak gerektiği unutulmamalıdır.

Yazarların Katkıları: Fikir/Kavram: B.Ö., D.D.O.; Tasarım: D.D.O.; Literatür Taraması: B.Ö., D.D.O.; Makale Yazımı: B.Ö., D.D.O.; Eleştirel İnceleme: D.D.O.

\section{KAYNAKLAR}

1. Burri L. The secrets of Krill [Adobe Digital Editions]. ISBN: 978-82-690452-0-8. Available from: https://cdn2.hubspot.net/hubfs/4650115/E-Book\%2020The\%20secrets\%20of\%20krill.pdf.

2. Singh J, Singh B, Kaur A. Krill oil - A novel food supplement for human health. Int J Food Sci Nutr. 2014; 3(6): 213-9.

3. Xie D, Gong M, Wei W, Jin J, Wang X, Wang X, et al. Antarctic Krill (Euphausia superba) oil: a 
comprehensive review of chemical composition, extraction technologies, health benefits, and current applications. Compr Rev Food Sci F. 2019; 18(2): 514-34.

4. Krill oil. Monograph. Altern Med Rev. 2010; 15(1): 84-6.

5. Yurko-Mauro K, Kralovec J, Bailey-Hall E, Smeberg V, Stark JG, Salem N. Similar eicosapentaenoic acid and docosahexaenoic acid plasma levels achieved with fish oil or Krill oil in a randomized double-blind four-week bioavailability study. Lipids Health Dis. 2015; 14(1): 99.

6. Ulven SM, Kirkhus B, Lamglait A, Basu S, Elind E, Haider, T, et al. Metabolic effects of Krill oil are essentially similar to those of fish oil but at lower dose of EPA and DHA in healthy volunteers. Lipids. 2011; 46(1): 37-46.

7. Vigerust NF, Bjørndal B, Bohov $\mathrm{P}$, Brattelid $\mathrm{T}$, Svardal A, Berge RK. Krill oil versus fish oil in modulation of inflammation and lipid metabolism in mice transgenic for TNF- $\alpha$. Eur J Nutr. 2013; 52(4): 1315-25.

8. Ierna M, Kerr A, Scales H, Berge K, Griinari M. Supplementation of diet with Krill oil protects against experimental rheumatoid arthritis. BMC Musculoskelet Disord. 2010; 11(1): 136.

9. Parastoo MZA, Kianpour Rad S. Anti-pain and antiinflammation like effects of Neptune Krill oil and fish oil against carrageenan induced inflammation in mice models: current statues and pilot study. Biotechnol Rep. 2019; 22(1): e00341.

10. Deutsch L. Evaluation of the effect of neptune Krill oil on chronic inflammation and arthritic symptoms. J Am Coll Nutr. 2007; 26(1): 39-48.

11. Bunea RE, Farrah K, Deutsch L. Evaluation of the effects of neptune Krill oil on the clinical course of hyperlipidemia. Altern Med Rev. 2004; 9(4): 420-8.

12. Berge K, Musa-Veloso K, Harwood M, Hoem N, Burri L. Krill oil supplementation lowers serum triglycerides without increasing low-density lipoprotein cholesterol in adults with borderline high or high triglyceride levels. Nutr Res. 2014; 34(2): 126-33.

13. Zhu JJ, Shi JH, Qian WB, Cai ZZ, Li D. Effects of Krill oil on serum lipids of hyperlipidemic rats and human SW480 cells. Lipids Health Dis. 2008; 7(1): 30.

14. Ferramosca A, Conte A, Burri L, Berge K, De Nuccio F, Giudetti AM, et al. A Krill oil supplemented diet suppresses hepatic steatosis in high-fat fed rats. PloS one. 2012; 7(6): e38797.

15. Cicero AFG, Rosticci M, Morbini M, Cagnati M, Grandi E, Parini A, et al. Lipid-lowering and antiinflammatory effects of omega 3 ethyl esters and Krill oil: a randomized, cross-over, clinical trial. Arch Med Sci. 2016; 12(3): 507-12.

16. Rundblad A, Holven KB, Bruheim I, Myhrstad MC, Ulven SM. Effects of Krill oil and lean and fatty fish on cardiovascular risk markers: A randomised controlled trial. J Nutr Sci. 2018; 7(e3): 1-11.

17. Sampalis F, Bunea R, Pelland MF, Kowalski O, Duguet N, Dupuis S. Evaluation of the effects of neptune Krill oil ${ }^{\mathrm{TM}}$ on the management of premenstrual syndrome and dysmenorrhea. Altern Med Rev. 2003; 8(2): 171-9.

18. Wibrand K, Berge K, Messaoudi M, Duffaud A, Panja D, Bramham CR, et al. Enhanced cognitive function and antidepressant-like effects after Krill oil supplementation in rats. Lipids Health Dis. 2013; 12(1): 6.

19. Gamoh S, Hashimoto M, Yanagimoto K, Katakura M, Abdul HM, Shido O. Krill-derived phospholipids rich in n-3 fatty acid improve spatial memory in adult rats. J Agric Sci. 2011; 3(4): 1-12.

20. Fosshaug LE, Berge RK, Beitnes JO, Berge K, Vik H, Aukrust P, et al. Krill oil attenuates left ventricular dilatation after myocardial infarction in rats. Lipids Health Dis. 2011; 10(1): 245.

21. Braarud H, Markhus M, Skotheim S, Stormark K, Frøyland L, Graff I, et al. Maternal DHA status during pregnancy has a positive impact on infant problem solving: a Norwegian prospective observation study. Nutrients. 2018; 10(5): 529. 